Introduction Atopic dermatitis and obstructive bronchitis are very often in our doctor's office and these diseases require strong commitments, frequent examinations and allergy tests.

Objective Association of atopic dermatitis and obstructive bronchitis in children at age of $0-3$ years.

Material and Methods We processed the data for 476 children treated during the period of 3 years. We used the data from childrens medical records, laboratory tests and reports of pulmo-allergology examinations. For processing the data we used analytic and descriptive method.

Results We processed the data for 476 children at age of $0-3$ years for the period from 2009-2011. We found atopic dermatitis in 141 children (29.6\%), atopic dermatitis associated with obstructive bronchitis in 63 children (44.6\%). Family anamnesis was positive in 86 children $(60.9 \%)$. The results from laboratory tests showed that the total IgE had increased in 54 children ( 67 children were tested), Eosinophiles were increased in all of them and we found positive specific IgE in 23 children ( 42 children were tested). We put 35 children on antihistaminic prevention. We used bronchodilatators in the treatment of acute attacks. All of the children who have increased IgE and positive specific IgE are examined regulary, not only from the family physicians, but also from pediatric pulmonologists. So, the percentage of hospitalized children is about $1.5 \%$.

Conclusion Early diagnosis and laboratory detection of atopic dermatitis and obstructive bronchial diseases as well, are of great importance for normal growth and development of children.

\section{INFLUENCE OF HALOTHERAPY ON OXIDANT-ANTIOXIDANT PROCESSES IN CHILDREN WITH DERMATO-RESPIRATORY SYNDOME AT THE PERIOD OF EXACERBATION OF ATOPIC DERMATITIS}

doi:10.1136/archdischild-2012-302724.0493

N Snyetkova, F Kokten. Crimea State Medical University, Simferopol, Ukraine

Methods 69 children aged from 2 to 15 years old with DRS. The group was made of 35 children with DRS, received traditional complex of medicinal measures with included halotherapy - treatment under the conditions of artificial microclimate of saline caves.

Results of investigation and conclusions The analysis of the data obtained allowed to reveal that children in the period of atopic dermatitis exacerbation manifest a considerable increase in the intensity of oxidant proceses on admission relatively-DK$1,318 \pm 0,015, \mathrm{MDA}-2,020 \pm 0,023, \mathrm{OMP} / \%$ of protein $55 \pm 0,121, \mathrm{OMP}$ Units of optic density/1 gr protein - 0,526 $\pm 0,025 \mathrm{OMP} / 1 \mathrm{ml}$ serum

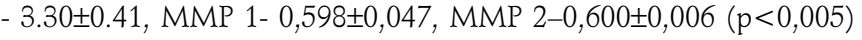
and.decrease antioxidant proceses KAT- $16.21 \pm 0.67 \mathrm{mkmol} / \mathrm{ml}$, AABS- $0,321 \pm 0.83 \mathrm{mmol} / \mathrm{ml}$. On discharge the indexes in both groups of children lowered, had reliability with control, only in group of children receiving halotherapy relatively DK - 0,878 $\pm 0,015$, $\mathrm{OMP} / \%$ protein $-48 \pm 0,087$, OMP Units of optic density/1 gr protein - 0,459 $\pm 0,015, \mathrm{OMP} / 1 \mathrm{ml}$ serum - 2.94 $\pm 0.12, \mathrm{MMP} 1-$ $0,250 \pm 0,015$, MMP 2- 0,325 $\pm 0,008$; KAT- $36.57 \pm 0.37 \mathrm{mkmol} / \mathrm{ml}$, AABS- $0,662 \pm 0.78 \mathrm{mmol} / \mathrm{ml}(\mathrm{p}<0,005)$. Halotherapy possesses antioxidant action and we recommend to include it into the complex of treatment of children with dermato-respiratory syndome, in exacerbation of atopic dermatitis on the stage of in-patient department.

\section{SPREADING OF BRONCHIAL ASTHMA AND RISK FACTORS IN CHILDREN'S POPULATION OF TBILISI AND BATUMI (ADJARIA REGION)}

doi:10.1136/archdischild-2012-302724.0494

${ }^{1} \mathrm{~N}$ Adamia, ${ }^{2} \mathrm{~N}$ Katamadze, 'I Chkhaidze, ${ }^{3} \mathrm{~L}$ Jorjoliani, ${ }^{3} \mathrm{~K}$ Barabadze, ${ }^{4} \mathrm{~T}$ Gigauri, ${ }^{1}$ U Ubiria, ${ }^{4} \mathrm{~L}$ Pachuashvili, ${ }^{4} \mathrm{~V}$ Zerekidze, ${ }^{4} \mathrm{~L}$ Saginadze, ${ }^{5} \mathrm{D}$ Khachapuridze. 'Department of General
Pediatrics, Tbilisi State Medical University; 'Batumi Regional Center of Family Medicine; ${ }^{3} / v a n e$ Javakhishvili State University; ${ }^{4} \mathrm{M}$. Iashvili Pediatric Clinic, Tbilisi; ${ }^{5}$ Kutaisi Pedagogical University, Kutaisi, Georgia

Goal Study of spreading of bronchial asthma (BA) and risk factors in the climate of the region of Georgia in children's populations of Tbilisi and Batumi.

Materials and methods Study included 4559 children of Tbilisi and Batumi of 5-16 age, 2193 girls, 2366 boys. Children's population was selected by cluster method. At the first stage identification of BA symptoms was provided based on the questionnaire. At the second stage clinical-allergological study of 389 children with positive answers took place. Obtained data were processed by means of SPSS/v12.5 software. Evaluation of degree of association between probability of disease and certain risk-factor was provided based on tetrachoric table $(2 \times 2)$.

Obtained results BA symptoms were analysed, distribution frequency by sex, set of diagnostic criteria was reliably high $(p=0.002)$ among boys. Obtained results showed that in Batumi BA diagnosis was made in $6.4 \%$ of cases and on Tbilisi - in $4.6 \%$ of cases.

Clinical-allergological study showed that among children with BA number of boys exceeded girls $(p<0.01)$. BA factors included: humidity $(76.4 \%)$, weather $(56.9 \%)$, cloudy and rainy weather (44.3\%), season $(24.6 \%)$, tobacco smell $(29.8 \%)$, respiratory infections $(34.2 \%)$, dust $(28.5 \%)$, physical load (19.7), medicament sensibilization $(11.2 \%)$ etc.

Conclusion Epidemiological study showed high BA frequency in Batumi (6.4\%), compared with Tbilisi children's population (4.6\%). Identification of risk factors provides basis for development of prevention programs. Data of BA spreading obtained by this study are dramatically different from official data $(0.4 \%)$ showing high frequency of hipodiagnostiscs of bronchial asthma in region $(p<0.01)$.

\section{MATERNAL AND ENDOGENOUS IGA PROTECTION IN INFANTS WITH RESPIRATORY TRACT INFECTIONS}

doi:10.1136/archdischild-2012-302724.0495

${ }^{1 B}$ Neamtu, ${ }^{2} \mathrm{O}$ Ketney, ${ }^{2} \mathrm{AM}$ Tita, ${ }^{2} \mathrm{~T}$ Ovidiu, ${ }^{3} \mathrm{M}$ Hila, ${ }^{4} \mathrm{M}$ Melaniea, ${ }^{5} \mathrm{LM}$ Neamtu, ${ }^{1} \mathrm{C}$ Neamtu. 'Research, Pediatric Hospital, Lucian Blaga University Sibiu; ${ }^{2}$ Agricultural Sciences and Food Engineering, Faculty of Agricultural Sciences, Food Industry and Environment Protection, Lucian Blaga University Sibiu, '3aboratory Research, Pediatric Hospital, Lucian Blaga University Sibiu; ${ }^{4}$ Laboratory Research, Pediatric Hospital Sibiu; ${ }^{5}$ Pediatric Hospital, Lucian Blaga University, Sibiu, Romania

Background Intestinal Ig A protection in infants relies both on maternal human milk sIgA (secretory immunoglobulin A) controlled by chemokines like CCL28, with roles of amplifying mammary secretion and passive gut epithelium transfer, and endogenous production. Probiotic strains from human milk and their substrate oligosaccharides derived from lactosis may stimulate local Ig A production in infants.

Objectives Assessing the levels of IgA in human milk and in infant's serum and lactosis levels from human milk, in breastfed infants with respiratory tract infections.

Methods We have evaluated 40 pairs mother- infant, healthy mothers, infants with respiratory tract infections. Human milk samples were analysed for physical and chemical properties on an ultrasonic infrared spectrometric analyser (ph, temperature, density, conductivity, fat composition, lactosis levels). Ig A, Ig M, IgG levels and protein profiles from human milk were measured after centrifugation by immunoturbidimetry method on a spectrophotometer and by protein electrophoresis with celullose acetate membrane respectively. Serum Ig A, Ig M, IgG levels from infants were determined using the same immunoturbidimetry method. Pearson correlations were studied in accordance to study's objectives.

Results Positive correlations statistically significant $(p<0.05)$ were found both between serum IgA and Ig G and human milk IgG. 